\title{
PENGEMBANGAN MESIN PENGUPAS KULIT BUAH AREN DENGAN METODE QUALITY FUNCTION DEPLOYMENT (QFD)
}

\author{
Robert Napitupulu ${ }^{1}$, Zaldy Sirwansyah Suzen ${ }^{2}$ \\ 1,2Jurusan Teknik Mesin - Politeknik Manufaktur Negeri Bangka Belitung \\ Kawasan Industri Air Kantung, Sungailiat-Bangka, 33211 \\ Tel: 0717-93586, Fax: 0717-93585, rnapitupulu77@gmail.com
}

\begin{abstract}
This study aims to determine whether the development of palm fruit peeler machine by using Quality Function Deployment (QFD) can optimize the results of the palm fruit peeling in Balun ljuk village, Bangka. The method used in the data collection is to survey the place, interview and distribute the questionnaires to the respondents. While the analysis of the data is by using the descriptive methods. The data obtained is analyzed by using the QFD, while the design and the engine development is made based on the analysis and interpretation of the House of Quality (HOQ), which is the result of QFD. Furthermore, to determine whether the tool is made completely in accordance with the demand of the consumer, then the machine is made and the tests to determine the level of need and customer satisfaction. The result of the study shows that the machine is able to peel more and the result of the peeling is that the machine can separate the skin from the seed by using the motor of 1PK electric power. While from the consumen satisfaction, it can be concluded that the price is affordable, the machine is durable and not easily porous, the performance of the tool is fast, it is easy to be operated, it saves more space, and easy to replace the spare parts.
\end{abstract}

Keywords: Consumen statisfaction, HOQ, Quality Function Deployment (QFD).

\begin{abstract}
Abstrak
Penelitian ini bertujuan untuk mengetahui bahwa rancang bangun mesin pengupas buah aren dengan menggunakan metode Quality Function Deployment (QFD) dapat mengoptimalkan hasil pengupasan buah aren di desa Balun ljuk Kabupaten Bangka. Objek penelitian yang digunakan dalam penelitian ini adalah masyarakat di Desa Balun ljuk Kabupaten Bangka sebagai penghasil kolang-kaling, diantaranya pengusaha dan para tenaga kerja yang mengupas kulit buah aren berjumlah 30 orang Responden. Metode pengumpulan data yang digunakan adalah survei ketempat pembuatan kolangkaling, wawancara dan menyebarkan kuisioner kepada para responden, sedangkan untuk menganalisanya menggunakan metode deskriptif. Data yang diperoleh dianalisa menggunakan QFD, desain dan Pengembangan mesin yang dilakukan berdasarkan analisis dan interpretasi terhadap House of Quality (HoQ) yang merupakan hasil dari QFD. Selanjutnya, untuk mengetahui apakah alat yang dibuat benar-benar sesuai dengan keinginan konsumen, maka mesin tersebut dibuat dan dilakukan ujicoba untuk mengetahui tingkat kebutuhan dan kepuasan pelanggan.
\end{abstract}

Kata kunci : HoQ, kolang-kaling, pengupas, QFD, responden.

\section{PENDAHULUAN}

Kolang-kaling adalah nama cemilan kenyal berbentuk lonjong dan berwarna putih transparan dan mempunyai rasa yang menyegarkan. Kolang kaling yang dalam bahasa Belanda biasa disebut glibbertjes [1] ini, dibuat dari biji pohon aren yang berbentuk pipih dan bergetah. Kolang-kaling memiliki kadar air sangat tinggi, hingga mencapai 93,8\% dalam setiap 100 gram-nya. Kolang kaling juga mengandung 0,69 gram protein, empat gram karbohidrat, serta kadar abu sekitar satu gram dan serat kasar 0,95 gram. Selain memiliki rasa yang menyegarkan, mengonsumsi kolang kaling juga membantu memperlancar kerja saluran cerna manusia. Kandungan karbohidrat yang dimiliki kolang kaling bisa memberikan rasa

Pengembangan Mesin Pengupas Kulit Buah Aren dengan Metode Quality Function Development (Robert Napitupulu) 
kenyang bagi orang yang mengonsumsinya, selain itu juga menghentikan nafsu makan dan mengakibatkan konsumsi makanan jadi menurun, sehingga cocok dikonsumsi sebagai makanan diet[2].

Di Kabupaten Bangka, tepatnya di desa Balun ljuk, terdapat sebuah Industri Kecil Menengah (IKM) penghasil buah aren untuk dijadikan kolang-kaling.

Penelitian ini bertujuan untuk merancang sekaligus membuat peralatan/mesin pengupas buah aren yang nantinya dapat dimanfaatkan oleh IKM untuk memecahkan persoalan pengupasan buah aren. Pengupasan ini mempunyai arti penting karena dapat mengurangi waktu proses yang selama ini digunakan secara manual (buah aren direbus selama 1-2 Jam, kemudian didinginkan selama 1 jam, setelah itu buah aren dikupas dengan menggunakan pisau dapur atau peralatan sederhana lainnya).

Penelitian tentang mesin pengupas biji buah aren/kolang-kaling pernah dilakukan oleh mahasiswa Politeknik Manufaktur Negeri Bangka Belitung pada tahun 2012[3]. Mesin ini terbuat dari bahan baja stainlessteel. Proses pengupasan buah aren dilakukan dengan cara memasukkan buah aren kedalam hopper satu persatu, lalu tuas penekan diangkat agar buah aren bisa turun tepat diatas pisau penyayat yang berbentuk lingkaran. Setelah buah aren jatuh tepat diatas pisau, kemudian tuas/handle ditekan agar poros penekan bisa menekan buah aren hingga keluar bijinya (Gambar 1).

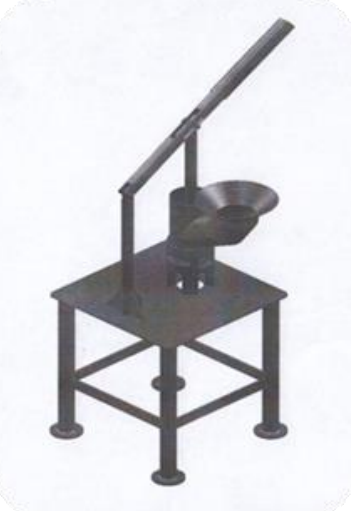

Gambar 1.Mesin Pengupas Buah Aren[3]

Hasil ujicoba dari alat tersebut, pengupasan buah aren dilakukan satu persatu dengan baik, namun masih ada persoalan yaitu kulit buah aren yang telah terkelupas masih tersangkut pada silinder penekan dan masih harus diungkit menggunakan alat bantu. Proses penekanan menggunakan manual dan membutuhkan tenaga yang cukup besar dan waktu pengerjaan masih cukup lama serta kapasitas produksi masih terlalu kecil.

Proses Perancangan dan pengembangan produk merupakan serangkaian aktivitas yang dimulai dari analisa persepsi dan peluang pasar, kemudian diakhiri dengan tahap produksi, penjualan dan pengiriman produk. Pengembangan produk dalam situasi dan kondisi apapun baik itu saat industri berubah cepat maupun stabil tetap mengandung resiko yang tinggi. Produk hasil pengembangan dikatakan sukses bila mendapat respon positif dari konsumen yang diikuti dengan keinginan dan tindakan untuk membeli produk. Mengidentifikasikan kebutuhan konsumen merupakan fase yang paling awal dalam mengembangkan produk, karena tahap ini menentukan arah pengembangan produk [4].

Akao[5], menyatakan bahwa untuk menterjemahkan kebutuhan dan keinginan konsumen ke dalam suatu rancangan produk yang memiliki persyaratan teknis dan karakteristik kualitas tertentu. Demikian juga menurut Cohen[6], Dalam proses perencanaan dan pengembangan produk untuk menetapkan spesifikasi kebutuhan dan keinginan konsumen, serta mengevaluasi secara sistematis kapabilitas suatu produk atau jasa dalam memenuhi kebutuhan dan keinginan konsumen. Dalam penentuan kualitas suatu produk sesuai keinginan konsumen tidak terlepas dari perancangan Eksperimen. Metasari[7], menyatakan desain eksperimen adalah suatu rancangan percobaan (dengan setiap langkah tindakan yang betul-betul terdefinisikan) sedemikian rupa sehingga informasi yang berhubungan untuk persoalan yang sedang diteliti dapat dikumpulkan dan suatu pengujian atau serangkaian pengujian yang bertujuan untuk melakukan perubahan terhadap variabel-variabel input dari proses atau sistem sehingga dapat meneliti dan mengidentifikasi sebab perubahan dari output. Metode ini berdasarkan pada pendekatan statistik yang pada awalnya dikembangkan untuk industri pertanian. Dari pengamatan awal yang telah dilakukan, peneliti merekomendasikan desain mesin 
pengupas kulit buah aren dengan memperhatikan suara konsumen (voice of customers) melalui metode Quality Function Deployment (QFD). Berdasarkan latar belakang diatas, identifikasi permasalahan penelitian ini dilakukan dengan menggunakan metode QFD. QFD adalah suatu metodologi yang terkenal untuk desain dan Pengembangan produk yang berorientasi pada pelanggan. Penerapan QFD ini diharapkan dapat memberikan solusi untuk perancangan serta pembuatan mesin pengupas buah aren untuk proses pembuatan kolang kaling.

\section{METODE PENELITIAN}

Dalam melakukan aktivitas penelitian diperlukan suatu metode yang sesuai dengan alur penelitian yang akan dilakukan. Adapun tahapan penelitian yang dilakukan mengikuti diagram alir pada Gambar 2 berikut:

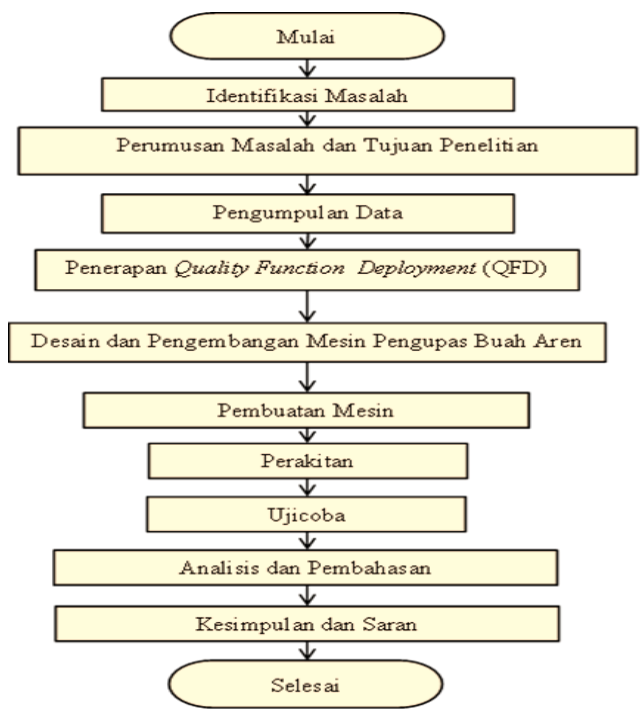

Gambar 2. flow chart Metode Penelitian yang digunakan

\section{HASIL DAN PEMBAHASAN}

Dalam menginventaris kebutuhan pelanggan, langkah pertama yang dilakukan adalah menyebarkan kuisioner kepada pelanggan yakni sebanyak 25 buah yang terdiri dari kuisioner yang bersifat umum dan khusus. Langkah selanjutnya melakukan rekapitulasi hasil kuisioner yang masuk, kemudian diteliti dan dilakukan pengecekan terhadap kuisioner yang diberikan. Dari beberapa Kuisioner yang masuk ada beberapa kuisioner yang tidak dapat diolah karena ketidaktahuan pelanggan/customer dalam mengisi dan memberikan jawaban atas Kuisioner yang diberikan. Tabel 1. berikut merupakan inventarisasi permintaan customer sesungguhnya.

\subsection{Pengelompokan Permintaan Customer}

Langkah selanjutnya adalah mengelompokkan atas permintaan kualitas customer. Hal ini bertujuan untuk menyederhanakan berbagai keinginan customer atau mengelompokkan permintaan yang sejenis. Tabel 2 menunjukkan pengelompokan permintaan kualitas customer. 
Tabel 1.

Tabel Inventaris Permintaan Kualitas Customer (PKC)

\begin{tabular}{|l|l|l|}
\hline No & \multicolumn{1}{|c|}{$\begin{array}{c}\text { Permintaan Kualitas Customer (PKC) } \\
\text { Tidak Terstruktur }\end{array}$} & Skor \\
\hline 1 & Aman dan mudah dalam pengoperasian & 24 \\
\hline 2 & Harga Mesin Ekonomis & 15 \\
\hline 3 & Kuat & 16 \\
\hline 4 & Tahan Karat & 10 \\
\hline 5 & Menggunakan Motor Penggerak Listrik & 17 \\
\hline 6 & Kapasitas Mesin yang diinginkan 20-30Kg jam & 18 \\
\hline 7 & Hiegenis & 15 \\
\hline 8 & Perawatan mudah & 20 \\
\hline 9 & Dimensinya sedang & 16 \\
\hline 10 & Bisa mengupas dan memisahkan antara kulit dan inti buah & 23 \\
\hline
\end{tabular}

Tabel 2.

Tabel Pengelompokan Permintaan Kualitas Customer

\begin{tabular}{|c|c|}
\hline No & Jenis Kelompok \\
\hline 1 & Safety \\
\hline 2 & Ekonomis \\
\hline 3 & Dimensi \\
\hline 4 & Fungsi \\
\hline
\end{tabular}

\subsection{Prioritas Permintaan Kualitas Customer}

Pada tahap ini adalah menentukan prioritas permintaan kualitas customer dengan cara melihat hasil kuisioner yang paling banyak dipilih oleh pelanggan untuk menentukan prioritas primer, sedang untuk menentukan skunder dan yang paling sedikit untuk menentukan tersier. Tabel 3 berikut merupakan hasil prioritas permintaan kualitas customer berdasarkan hasil kuisioner.

\subsection{Penyusunan Performance Kualitas Konstruksi (PKK)}

Langkah kedua dalam Substitute Quality Characteristic (SQC) adalah pertimbangan performance kualitas konstruksi (PKK). Dalam penyusunan performance kualitas konstruksi yaitu dengan menterjemahkan permintaan kualitas customer oleh desainer. Tabel 4 berikut menggambarkan performance kualitas konstruksi yang diinginkan.

Tabel 3.

Tabel Priontes Pemintaan Kualitas Customer (PKC)

Tabel Prionitas Pemintaan Kualitas Customer (PKC)
\begin{tabular}{|l|l|c|c|c|}
\hline No & \multicolumn{1}{|c|}{$\begin{array}{c}\text { Pemintaan Kualitas Customer } \\
\text { (PKC) Tidak Terstruktur }\end{array}$} & Voice & Keterangan & Persentase \\
\hline 1 & Aman dan mudah dalam pengoperasian & 24 & Primer & $96 \%$ \\
\hline 2 & Harga Mesin Ekonomis & 15 & Skunder & $60 \%$ \\
\hline 3 & Kuat & 16 & Skunder & $64 \%$ \\
\hline 4 & Tahan Karat & 10 & Skunder & $40 \%$ \\
\hline 5 & Menggunakan Motor Penggerak Listrik & 17 & Primer & $68 \%$ \\
\hline 6 & Kapasitas Mesin yang diinginkan 20-30Kgjam & 18 & Primer & $72 \%$ \\
\hline 7 & Hiegenis & 15 & Skunder & $60 \%$ \\
\hline 8 & Perarvatan mudah & 20 & Primer & $80 \%$ \\
\hline 9 & Dimensinva sedang & 16 & Skunder & $64 \%$ \\
\hline 10 & $\begin{array}{l}\text { Bisa mengupas dann memisahkan antara kulit } \\
\text { dan inti buah }\end{array}$ & 23 & Primer & $92 \%$ \\
\hline
\end{tabular}

Tabel 4.

Tibed Peformance Kualits Kostruki

\begin{tabular}{|c|c|c|}
\hline $\begin{array}{l}\text { Pemintan Kualitas Customer } \\
\text { (PKC) }\end{array}$ & $\begin{array}{c}\text { Peformance Rualitas Konstrokisi } \\
\text { (PKK) }\end{array}$ & Reerangn \\
\hline $\begin{array}{l}\text { Aman dan mudah dalam: } \\
\text { peagopensian }\end{array}$ & 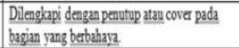 & PXK1 \\
\hline Harga Vesin Ekonomis & Harzan Vakimal 10 Juta Rupiah & PKK2 \\
\hline Kuat & $\begin{array}{l}\text { Mesin mampu mengups buah zen yang } \\
\text { banyzk }\end{array}$ & PKK3 \\
\hline Thanan Karat & Pisup pengupes dikeaskan haddening & PKK4 \\
\hline $\begin{array}{l}\text { Nenggunkan Motor Pengsenk. } \\
\text { Listrik }\end{array}$ & 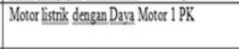 & PRK5 \\
\hline $\begin{array}{l}\text { Kapasitas Nkin yang dinginkan } \\
\text { 20-30Kg jam }\end{array}$ & Kappsitas 20.30 Kg $/ \mathrm{lm}$ & PKR6 \\
\hline Hiegenis & Hasil pengposan buah aren & PKKT \\
\hline Pearaztan mudah & \begin{tabular}{|l|} 
Sulucadang tessedia dipserman \\
\end{tabular} & PKK8 \\
\hline Dimensinz seding & Ukuran mein tidaktelala' bessa dan kecil & PKK9 \\
\hline $\begin{array}{l}\text { Biss mengypas dan memighton } \\
\text { atan kulit dan int buah }\end{array}$ & 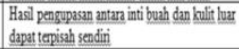 & PKK10 \\
\hline
\end{tabular}

\subsection{Strukturisasi Performance Kualitas Konstruksi}

Pada tahap ini adalah pembuatan strukturisi performance kualitas konstruksi dengan mengacu pada prioritas PKK yang didapat dari customer melalui SQC. Tabel 5 berikut menunjukkan strukturisasi performance kualitas konstruksi.

\subsection{Rumah Kualitas (House of Quality)}

Pada tahap ini adalah menggabungkan beberapa matrik yang telah dibuat sebelumnya yakni permintaan kualitas customer dan performance kualitas konstruksi. Gambar 3 berikut adalah rumah kualitas yang dibuat berdasarkan matrik yang telah disusun. 
Tabel 5.

\begin{tabular}{|c|l|c|}
\multicolumn{4}{|c|}{ Tabel Strukturisasi Performance Kualitas Konstruksi } \\
\hline Level & \multicolumn{1}{|c|}{ Performansi } & Keterangan \\
\hline Primer & $\begin{array}{l}\text { Dilengkapi dengan penutup atau cover pada bagian yang } \\
\text { berbahaya. }\end{array}$ & PKK1 \\
\hline Skunder & Harga Maksimal 10 Juta Rupiah & PKK2 \\
\hline Skunder & Mesin mampu mengupas buah aren yang bannak & PKK3 \\
\hline Skunder & Pisau pengupas dikeraskan hardening & PKK4 \\
\hline Primer & Motor listrik dengan Daya Motor 1 PK & PKK5 \\
\hline Primer & Kapasitas 20-30 KgJam & PKK6 \\
\hline Skunder & Hasil pengupasan buah aren & PKK7 \\
\hline Primer & Sukucadang tersedia dipasaran & PKK8 \\
\hline Skunder & Ukuran mesin tidak terlalu besar dan kecil & PKK9 \\
\hline Primer & $\begin{array}{l}\text { Hasil pengupasan antara inti buah dan kulit luar dapat terpisah } \\
\text { sendiri }\end{array}$ & PKK10 \\
\hline
\end{tabular}

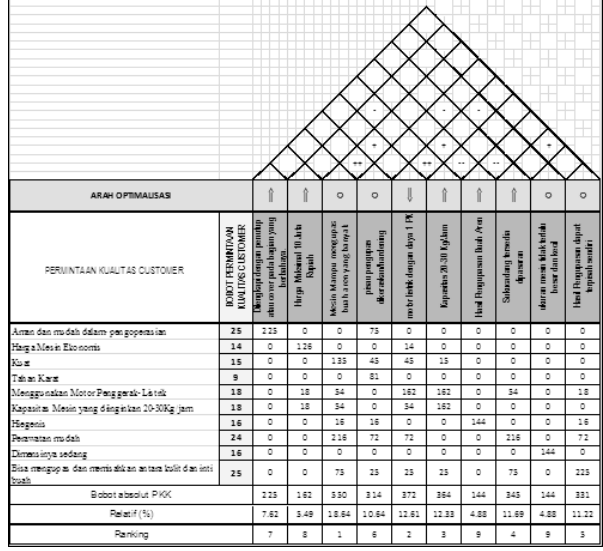

Gambar 3. Rumah Kualitas (House of Quality)

\subsection{Hasil Pengembangan Mesin}

Pada tahap ini adalah mendesain mesin pengupas buah aren sesuai dengan tuntutan customer melalui Pengembangan dari yang telah ada saat ini. Pengembangan mesin ini melihat beberapa aspek yang dominan atau berdasarkan ranking dari rumah kualitas (House of quality). Hasil dari Pengembangan mesin tersebut seperti ditunjukkan pada Gambar 4 berikut ini.

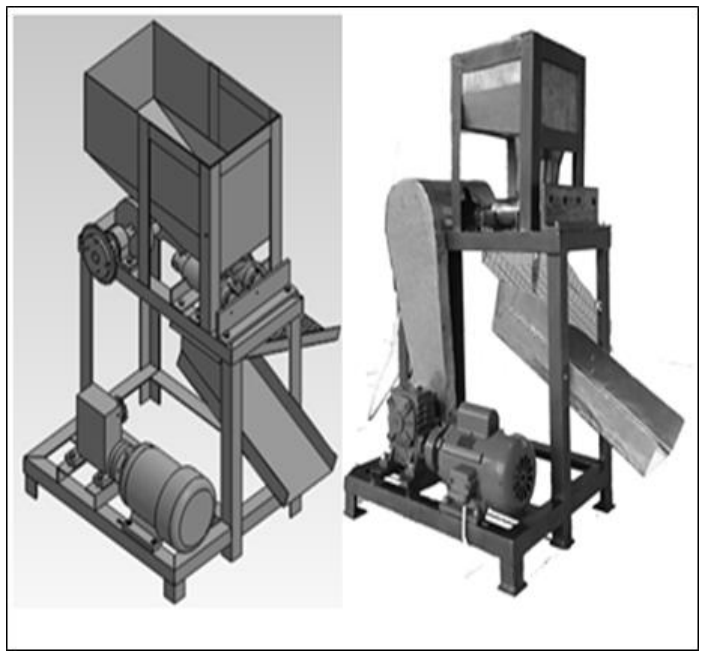

Dengan spesifikasi mesin:

- Dimensi : 970x600x500 mm

- Motor Penggerak Ac $1 / 2$ PK

- Sistem Transmisi menggunakan rantai dan sprocket

- Rasio 1:10

- Kapasitas $30 \mathrm{Kg} / \mathrm{jam}$

Gambar 4. Hasil Pengembangan mesin pengupas buah aren

\section{SIMPULAN}

Berdasarkan hasil pembahasan masalah dalam Pengembangan mesin pengupas buah aren, dapatlah disimpulkan sebagai berikut:

1) Konsep rancang bangun mesin pengupas buah aren dengan menggunakan metode QFD (Quality Function Deployment) menggunakan urutan bobot nilai, sesuai dengan yang diinginkan oleh konsumen yaitu : mesin mampu mengupas buah aren yang banyak, hasil pengupasan dapat terpisah antara kulit dan inti, motor listrik dengan daya 1PK, pelindung bagian yang berbahaya ada dalam QFD (Quality Function Deployment).

2) Dari beberapa yang diinginkan oleh konsumen ada beberapa komponen yang merupakan kelebihan dari mesin pengupas buah aren yang telah dibuat dengan produk sebelumnya yaitu mesin dilindungi pada bagian yang berbahaya, harga yang terjangkau, awet dan tidak mudah keropos, kinerja alat cepat, mudah dioperasikan, hemat tempat, mudah penggantian parts. 


\section{DAFTAR PUSTAKA}

[1]. Wikipedia Ensiklopedia Bebas, Kolang kaling, [Online], diakses pada 9 April 2015, Available: http://id.wikipedia.org/.

[2]. Wikipedia Ensiklopedia Bebas, Enau, [Online], diakses pada 9 April 2015, Available: http://id.wikipedia.org/.

[3]. Pahyudi, K., Randi, K., dan Resdianto. Z., (2012), "Alat Pengupas Buah Aren”, Laporan Akhir PKMT, Politeknik Manufaktur Negeri Bangka Belitung, Sungailiat.

[4]. Ulrich, Karl .T., dan Steven D. Eppinger, (1995), Product Design and Development, McGraw-Hill International.

[5]. Akao, Y., (1990), Quality Function Deployment: Intergrating Customer Requirement Into Product Design, Massachusets: Productivity Press.

[6]. Cohen, Lou., (1995), Quality Function Deployment : How To Make QFD Work For You, Massachuset : Addison-Wesley Publishing Company.

[7]. Metasari, Nur, (2010), Design of Experiment, [online], diakses pada 4 April 2015, Available:http://qualityengineering.wordpress.com. 